\title{
ENGINEERING ECONOMICS AND LIFE CYCLE COST ANALYSIS
}

\author{
Dhruv J. Desai ${ }^{1}$, Tejas H. Jain ${ }^{2}$, Atul A. Dwivedi ${ }^{3}$, Anjum D. Attar ${ }^{4}$ \\ ${ }^{I}$ M.H.SabooSiddik College of Engineering, Maharashtra, India \\ ${ }^{2}$ M.H.SabooSiddik College of Engineering, Maharashtra, India \\ ${ }^{3}$ M.H.SabooSiddik College of Engineering, Maharashtra, India \\ ${ }^{4}$ M.H.SabooSiddik College of Engineering, Maharashtra, India
}

\begin{abstract}
Life-cycle cost analysis (LCCA) is anevaluating tool to valuate the total financial/resource requirements for total ownership of a building. LCCA is effective when project options that fulfill the same task demands, having different initial costs and operational costs, needs to be examined in order to undertake the option that optimizes financial requirements.

Building-related expenses can be furthercategorized into the following:

- Initial Costs

- Operation, Maintenance, and Repair Costs

- Replacement Costs

- Residual Values

- Finance Charges

- Non-Monetary Costs

This article mainly focuses on the Maintenance and Repair cost analysis; giving probable trends for next 25 years for various elements using DSR, WPI and CPI. These trends are only applicable for the whole of Mumbai.
\end{abstract}

Keyordsw: Life Cycle Cost, Maintenance and Repair cost.

\section{LIFE CYCLE COST ANALYSIS}

.Life Cycle Cost Analysis is a method of estimating the economic performance of a building over its life period. It is also known as "whole cost accounting" or "total cost of ownership," LCCA balances the intial stage investment with life period costs including owning cost and operating cost of that particular building.

LCCA is calculated on the premises that different building design alternatives can accomplish the same functions with the same amount of efficiency. These options having different initial costs, operational costs, maintenance and repair costs and may also differ in life cycle periods. Considering a particular alternative, LCCA forecasts the total cost of building, including initial construction cost, operation and maintenance cost, for a particular life of the building, cited as "study period".

Life cycle cost analysis helps in maintaining a balance between the initial cost of any alternative process adopted and long term cost saving of that alternative process. LCCA also helps in narrowing the most cost effective alternative and also calculates the "payback" period of the increased cost. To estimate life cycle cost for allapplicable alternatives is not feasible, and therefore the guiding principle for LCCA considers the one which affects the long-term expenses.

\subsection{Importance of LCCA}

[1].As the CHART-1 below depicts 30 year cost analysis of a building's life, including its construction costs, its maintenance costs, operation costs, and utility costs.
$* * *$

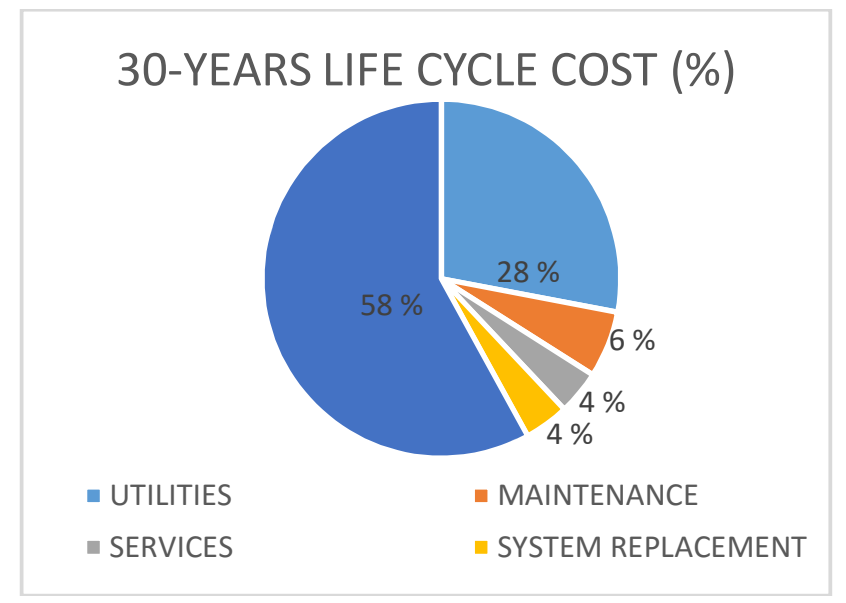

CHART-1:30-YEAR ANALYSIS

Since it is evident that for a 30 -year period, maintenance cost accounts nearly $6 \%$ of the total cost, the Maintenance and Repair cost analysis will be the prime focus of this article.

\section{MAINTENANCE AND REPAIR}

Building repairs and maintenance mainly consists ofconserving proper state of a building, its functions and utilities in routine use.

The types of building repair and maintenance are:

- Day to day repairs service facilities

- Annual repairs

- Special repairs

- Additions and alterations

- Preventive maintenance 


\section{RESEARCH METHODOLOGY}

The maintenance and repair costs are found for various elements that are subjected to maintenance and repairs. The cost of these elements are gathered from the DISTRICT SCHEDULE OF RATES OF MUMBAI AND SUBURBAN AREA over the last 15 years ie. from year 2001. SinceDISTRICT SCHEDULE OF RATES OF MUMBAI AND SUBURBAN AREA is used, these trnds are only applicable to Mumbai district. These rates are consideredas the basis for the projected cost over the next 25 years ie. till year 2040. Basic rates for cistern fittings and labour wages have been collected from the WHOLESALE PRICE INDEX and CONSUMER PRICE INDEX respectively corresponding forecast is developed. Forecasts are developed with the help of trendlines characterized by specific curve equations thereby giving projected rates.

\section{ELEMENTS CONSIDERED FOR} MAINTENANCE

Next 25 years of cost projections for following maintenance elements have been determined:-

1. INTERNAL PLASTERING

2. EXTERNAL PLASTERING

3. INTERNAL OIL PAINTING

4. CISTERN FITTINGS

5. DEDO TILING

6. FLOORING

The main reason behind selecting these elements lies in the fact that these maintenance and repair parameters are the most common and most widely subjected in reference to maintenance and repair works.

\subsection{Internal Plastering}

DESCRIPTION: The analysis considers internal plastering being undertaken in single coat, having $12 \mathrm{~mm}$ thickness. The plaster is prepared in cement to water ratio 1:5. Cost of neeru finish has been neglected in this analysis. The cost of scaffolding required and curing provided has been considered.

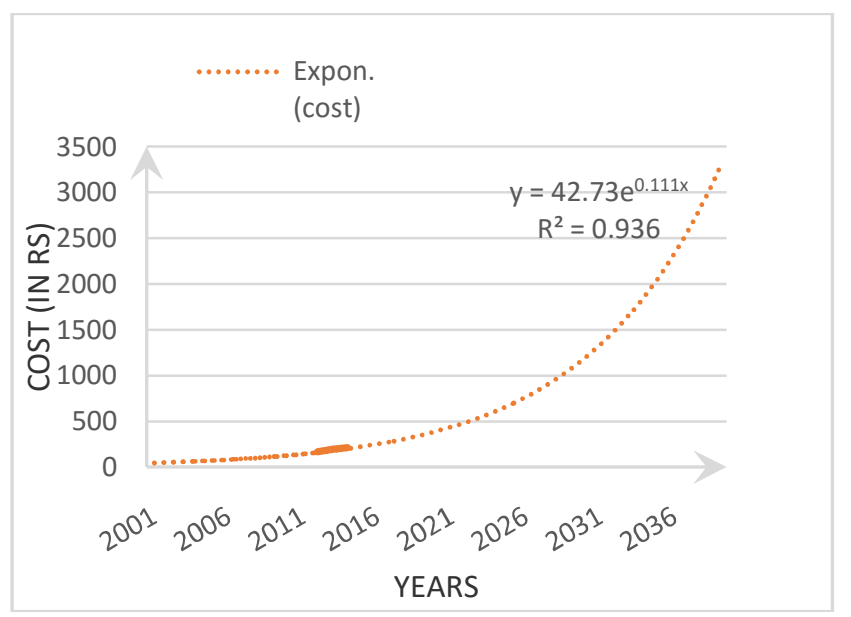

Chart 2: Cost Projections For Internal Plastering
Table 1: Cost Projections For Internal Plastering

\begin{tabular}{|l|l|l|l|}
\hline YEARS & $\begin{array}{l}\text { PROJECTED } \\
\text { COST(Rs/Sqm) }\end{array}$ & YEARS & $\begin{array}{l}\text { PROJECTED } \\
\text { COST(Rs/Sqm) }\end{array}$ \\
\hline 2016 & 263.5237 & 2029 & 1030.573 \\
\hline 2017 & 292.6699 & 2030 & 1144.556 \\
\hline 2018 & 325.0397 & 2031 & 1271.146 \\
\hline 2019 & 360.9897 & 2032 & 1411.737 \\
\hline 2020 & 400.9158 & 2033 & 1567.878 \\
\hline 2021 & 445.2579 & 2034 & 1741.288 \\
\hline 2022 & 494.5042 & 2035 & 1933.878 \\
\hline 2023 & 549.1973 & 2036 & 2147.768 \\
\hline 2024 & 609.9395 & 2037 & 2385.315 \\
\hline 2025 & 677.3999 & 2038 & 2649.135 \\
\hline 2026 & 752.3216 & 2039 & 2942.135 \\
\hline 2027 & 835.5297 & 2040 & 3267.54 \\
\hline 2028 & 927.9408 & & \\
\hline
\end{tabular}

\subsection{External Plastering}

DESCRIPTION: Rough cast cement plaster is considered for external plastering. The plastering is provided in two coats to concrete, stone or brickmasonary. The analysis also includes preparing the base and watering the surface. The base coat is 12 to $15 \mathrm{mmthick}$, prepared in cement to water ratio of 1:4. The analysis also considers water proofing of the surface using water proofing compound at the rate of 1 $\mathrm{kg}$ per $50 \mathrm{~kg}$ of cement. Rough cast treatment provided is 12 $\mathrm{mm}$ thick and in proportion 1:1.5:3 (cement : sand : coarse aggregate). The cost of scaffolding required and curing provided for 14 days has been considered.

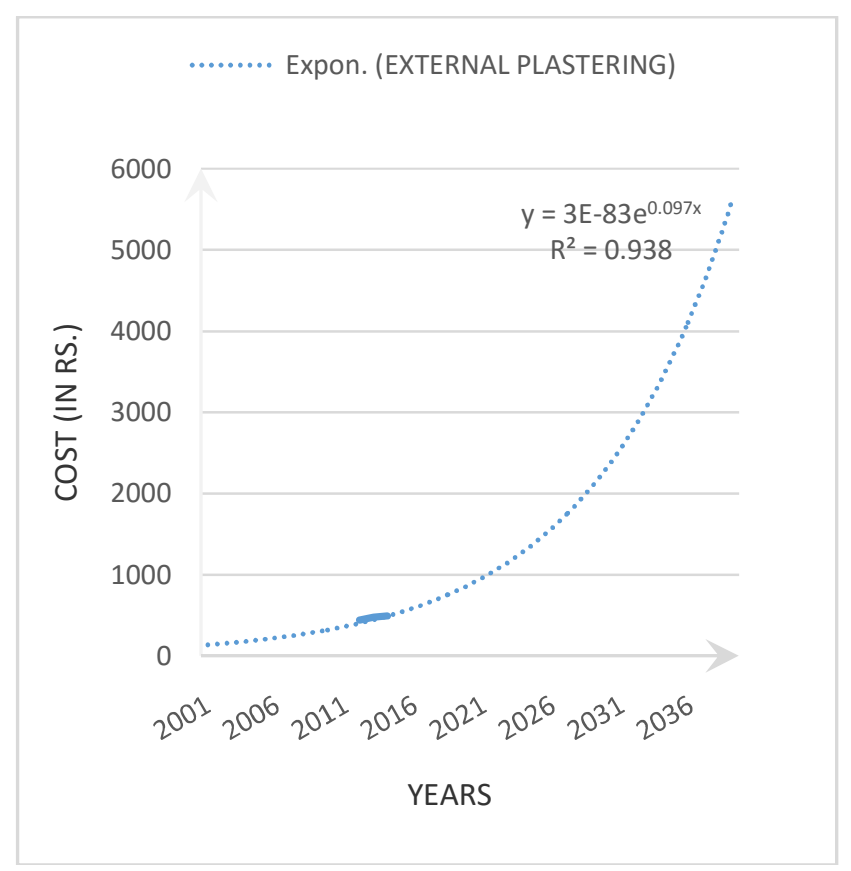

Chart 3: Cost Projections For External Plastering 
Table 2: Cost Projections For External Plastering

\begin{tabular}{|l|l|l|l|}
\hline YEAR & $\begin{array}{l}\text { PROJECTED } \\
\text { COST(Rs/Sqm) }\end{array}$ & YEAR & $\begin{array}{l}\text { PROJECTED } \\
\text { COST(Rs/Sqm) }\end{array}$ \\
\hline 2016 & 595.1564 & 2029 & 2008.143 \\
\hline 2017 & 653.5202 & 2030 & 2205.071 \\
\hline 2018 & 717.6076 & 2031 & 2421.311 \\
\hline 2019 & 787.9796 & 2032 & 2658.756 \\
\hline 2020 & 865.2527 & 2033 & 2919.487 \\
\hline 2021 & 950.1035 & 2034 & 3205.785 \\
\hline 2022 & 1043.275 & 2035 & 3520.16 \\
\hline 2023 & 1145.584 & 2036 & 3865.364 \\
\hline 2024 & 1257.925 & 2037 & 4244.42 \\
\hline 2025 & 1381.283 & 2038 & 4660.648 \\
\hline 2026 & 1516.739 & 2039 & 5117.694 \\
\hline 2027 & 1665.477 & 2040 & 5619.559 \\
\hline 2028 & 1828.802 & & \\
\hline
\end{tabular}

\subsection{Internal Oil Painting}

DESCRIPTION: Appling of an oil paint coat of required colour and of required shade to the building and workshop's plastered surface has been considered. Required scaffolding, surface preparation and cleaning is included.

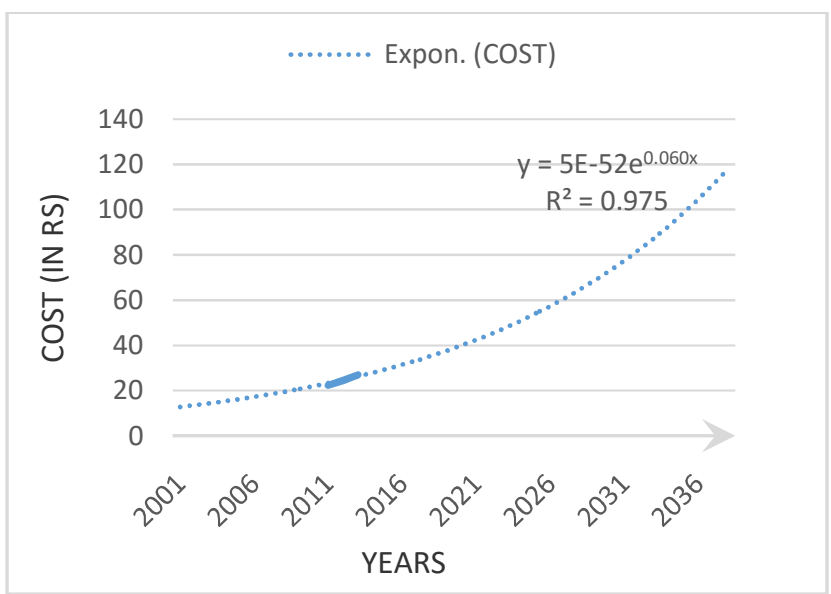

Chart 4: Cost Projection For Internal Oil Painting

Table 3: Cost Projection For Internal Oil Painting

\begin{tabular}{|l|l|l|l|}
\hline $\begin{array}{l}\text { YEA } \\
\text { RS }\end{array}$ & $\begin{array}{l}\text { PROJECTED } \\
\text { COST(Rs/Sqm) }\end{array}$ & $\begin{array}{l}\text { YEA } \\
\text { RS }\end{array}$ & $\begin{array}{l}\text { PROJECTED } \\
\text { COST(Rs/Sqm) }\end{array}$ \\
\hline 2016 & 30.75552 & 2029 & 63.50921 \\
\hline 2017 & 32.51975 & 2030 & 67.15229 \\
\hline 2018 & 34.38518 & 2031 & 71.00435 \\
\hline 2019 & 36.35762 & 2032 & 75.07738 \\
\hline 2020 & 38.4432 & 2033 & 79.38405 \\
\hline 2021 & 40.64842 & 2034 & 83.93776 \\
\hline 2022 & 42.98014 & 2035 & 88.75268 \\
\hline 2023 & 45.44561 & 2036 & 93.84381 \\
\hline 2024 & 48.05251 & 2037 & 99.22697 \\
\hline 2025 & 50.80895 & 2038 & 104.9189 \\
\hline 2026 & 53.7235 & 2039 & 110.9374 \\
\hline 2027 & 56.80525 & 2040 & 117.3011 \\
\hline 2028 & 60.06377 & & \\
\hline
\end{tabular}

\subsection{Cistern Fittings With Labour Wages}

\subsubsection{Cistern Fittings}

DESCRIPTION: Under cistern fittings only considerations regarding the regular taps that are used are made. Taps ranging from kitchen taps to toilet and bathroom taps and basin taps are considered here. The cost considered are average cost of taps in household. The base costs are gathered from the WHOLESALE PRICE INDEX.

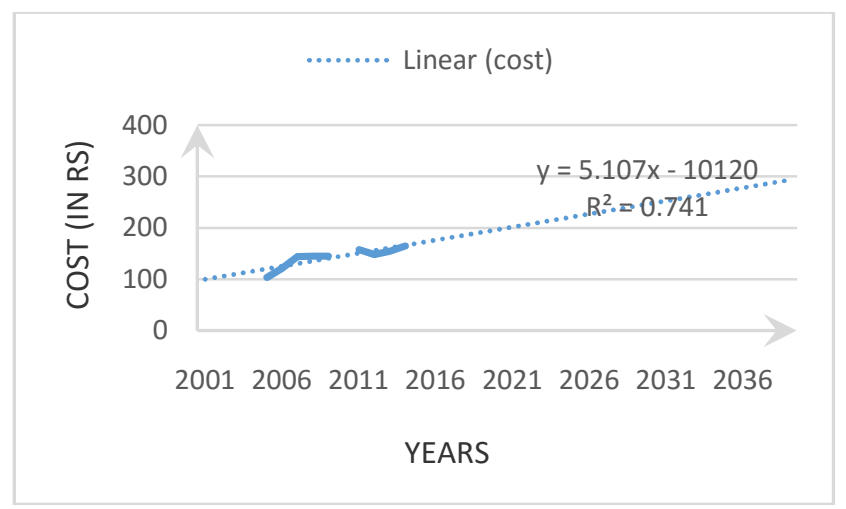

Chart 5: Cost Projection For Cistern Fittings

Table 4:Cost Projection For Cistern Fittings

\begin{tabular}{|l|l|l|l|}
\hline YEARS & $\begin{array}{l}\text { PROJECTED } \\
\text { COST(Rs/unt) }\end{array}$ & YEARS & $\begin{array}{l}\text { PROJECTED } \\
\text { COST(Rs/unt) }\end{array}$ \\
\hline 2016 & 175.0323 & 2029 & 242.0623 \\
\hline 2017 & 180.1885 & 2030 & 247.2185 \\
\hline 2018 & 185.3446 & 2031 & 252.3746 \\
\hline 2019 & 190.5008 & 2032 & 257.5308 \\
\hline 2020 & 195.6569 & 2033 & 262.6869 \\
\hline 2021 & 200.8131 & 2034 & 267.8431 \\
\hline 2022 & 205.9692 & 2035 & 272.9992 \\
\hline 2023 & 211.1254 & 2036 & 278.1554 \\
\hline 2024 & 216.2815 & 2037 & 283.3115 \\
\hline 2025 & 221.4377 & 2038 & 288.4677 \\
\hline 2026 & 226.5938 & 2039 & 293.6238 \\
\hline 2027 & 231.75 & 2040 & 298.78 \\
\hline 2028 & 236.9062 & & \\
\hline & & & \\
\hline
\end{tabular}

\subsubsection{Labour Requirement For Fittings}

DESCRIPTION: Skilled labour is considered for the fitting of taps. Since time requirement for the fixation of tap is nominal, generally unskilled labour wages are considered here. Since the base wages of the unskilled labour is collected from the CONSUMER PRICE INDEX references. 


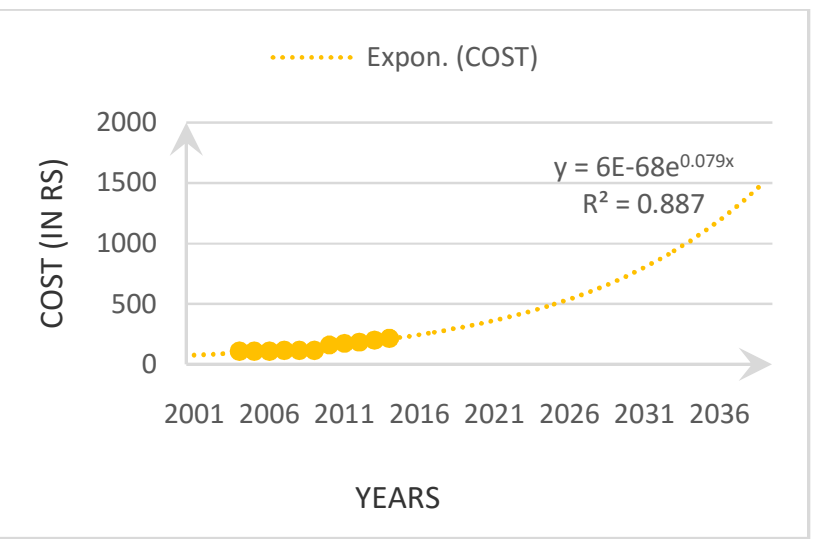

Chart 6: Cost Projection For Labour Wages

TABLE 5:COST PROJECTION FOR LABOUR WAGES

\begin{tabular}{|l|l|l|l|}
\hline $\begin{array}{l}\text { YEA } \\
\text { RS }\end{array}$ & $\begin{array}{l}\text { PROJECTED } \\
\text { COST(Rs/Hr) }\end{array}$ & $\begin{array}{l}\text { YEA } \\
\text { RS }\end{array}$ & $\begin{array}{l}\text { PROJECTED } \\
\text { COST(Rs/Hr) }\end{array}$ \\
\hline 2016 & 252.9275 & 2029 & 727.1442 \\
\hline 2017 & 274.331 & 2030 & 788.6773 \\
\hline 2018 & 297.5457 & 2031 & 855.4176 \\
\hline 2019 & 322.7249 & 2032 & 927.8056 \\
\hline 2020 & 350.0349 & 2033 & 1006.319 \\
\hline 2021 & 379.6559 & 2034 & 1091.477 \\
\hline 2022 & 411.7835 & 2035 & 1183.841 \\
\hline 2023 & 446.6298 & 2036 & 1284.021 \\
\hline 2024 & 484.425 & 2037 & 1392.679 \\
\hline 2025 & 525.4185 & 2038 & 1510.532 \\
\hline 2026 & 569.8809 & 2039 & 1638.357 \\
\hline 2027 & 618.106 & 2040 & 1777 \\
\hline 2028 & 670.412 & & \\
\hline
\end{tabular}

\subsection{DADO TILING}

DESCRIPTION:The analysis consists of providing and fixing plain ceramic tiles of size $300 \mathrm{~mm}$ X $200 \mathrm{~mm}$. The plaster used is cement mortar ratio of $1: 4$. The forecast includes filling of joints with neat cement flurry or cement paste. The cost also includes curing and cleaning after dado tiling is done.

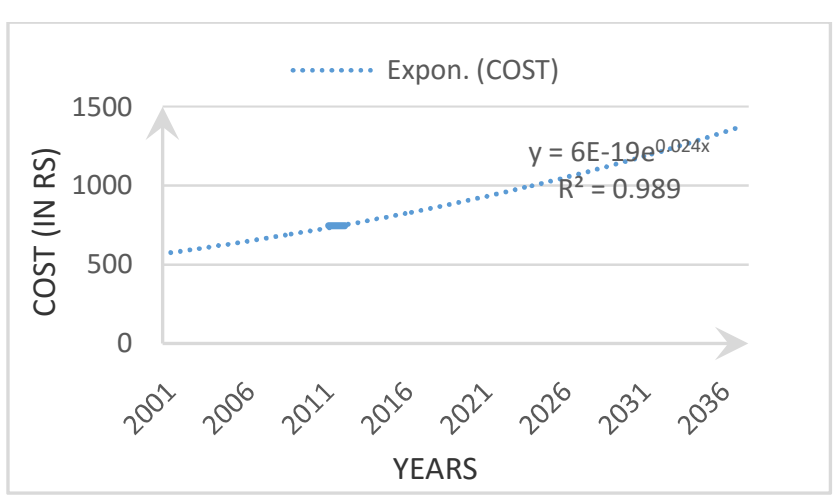

Chart 7: Cost Projection For Dado Tiling
Table 6: Cost Projection For Dado Tiling

\begin{tabular}{|l|l|l|l|}
\hline $\begin{array}{l}\text { YEA } \\
\text { RS }\end{array}$ & $\begin{array}{l}\text { PROJECTED } \\
\text { COST(Rs/Sqm) }\end{array}$ & $\begin{array}{l}\text { YEA } \\
\text { RS }\end{array}$ & $\begin{array}{l}\text { PROJECTED } \\
\text { COST(Rs/Sqm) }\end{array}$ \\
\hline 2016 & 813.9379 & 2029 & 1079.762 \\
\hline 2017 & 831.8262 & 2030 & 1103.492 \\
\hline 2018 & 850.1075 & 2031 & 1127.744 \\
\hline 2019 & 868.7907 & 2032 & 1152.529 \\
\hline 2020 & 887.8844 & 2033 & 1177.859 \\
\hline 2021 & 907.3978 & 2034 & 1203.745 \\
\hline 2022 & 927.34 & 2035 & 1230.2 \\
\hline 2023 & 947.7205 & 2036 & 1257.237 \\
\hline 2024 & 968.5489 & 2037 & 1284.867 \\
\hline 2025 & 989.8351 & 2038 & 1313.105 \\
\hline 2026 & 1011.589 & 2039 & 1341.964 \\
\hline 2027 & 1033.821 & 2040 & 1371.457 \\
\hline 2028 & 1056.542 & & \\
\hline
\end{tabular}

\subsection{FLOORING}

DESCRIPTION: The analysis consists of providing and laying of marble mosaic that is $10 \mathrm{~mm}$ thick. This flooring is made of marble chips of white orany other colour. These chips are preferably of $6 \mathrm{~mm}$ size. Coloured cement is more suitable for flooring. It also includes an under layer of cement concrete 1:2:4.Providing aluminium strips for panels, leveling, compacting, curing, polishing, rubbing and cleaning are considered in the analysis.

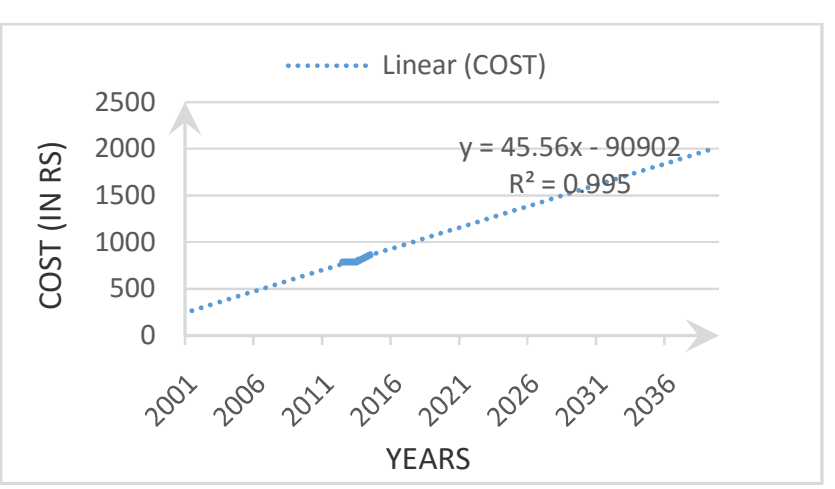

Chart 8: Cost Projection For Flooring

Table 7: Cost Projection For Flooring

\begin{tabular}{|l|l|l|l|}
\hline YEARS & $\begin{array}{l}\text { PROJECTED } \\
\text { COST(Rs/Sqm) }\end{array}$ & YEARS & $\begin{array}{c}\text { PROJECTED } \\
\text { COST(Rs/Sqm) }\end{array}$ \\
\hline 2016 & 989.7752 & 2029 & 1584.853 \\
\hline 2017 & 1035.55 & 2030 & 1630.628 \\
\hline 2018 & 1081.326 & 2031 & 1676.403 \\
\hline 2019 & 1127.101 & 2032 & 1722.178 \\
\hline 2020 & 1172.876 & 2033 & 1767.954 \\
\hline 2021 & 1218.651 & 2034 & 1813.729 \\
\hline 2022 & 1264.426 & 2035 & 1859.504 \\
\hline 2023 & 1310.202 & 2036 & 1905.279 \\
\hline 2024 & 1355.977 & 2037 & 1951.054 \\
\hline 2025 & 1401.752 & 2038 & 1996.83 \\
\hline 2026 & 1447.527 & 2039 & 2042.605 \\
\hline 2027 & 1493.302 & 2040 & 2088.38 \\
\hline 2028 & 1539.078 & & \\
\hline
\end{tabular}




\section{CONCLUSIONS}

Thus based on the trendlines of different activies/ process it can be conferred that the maintenance and repair costs are bound to increase as the time passes. Some tend to increase linearly while some tend to increase exponentially. These graphs will help the financial controllers and economy managers to predict the cost of specific repair and maintenance work in the future years. These predictions will assist to plan and manage the finances according to the requirement.

\section{ACKNOWLEDGEMENT}

We would like to thank and acknowledge the hard work and perseverance of Ms. Shagufta Sayed in guiding us and showing the correct path during the entire research period.

\section{REFERENCES}

1. Fuller, Sieglinde. "Whole Building Design Guide-Life Cycle Cost Analysis (LCCA)." (2004). https://www.wbdg.org/resources/lcca.php

2. GUIDELINES FOR LIFE CYCLE COST ANALYSIS https://lbre.stanford.edu/sites/all/lbreshared/files/docs_public/LCCA121405.pdf

3. Sayed, ShaguftaSajidMumtaaz, and Priyadarshi H. Sawant. "Life-cycle cost and financial analysis of energy components in mass housing projects-A case project in sub-urban India." International Journal of Sustainable Built Environment 4.2 (2015): 202-221.

4. Mumtaaz Sayed, ShaguftaSajid, and Priyadarshi H. Sawant. "Financial Feasibility Analysis of Water Conservation Components in Mass Housing Projects: Suburban Indian Case Review." Journal of Architectural Engineering (2016): 04016001.

\section{BIOGRAPHIES}

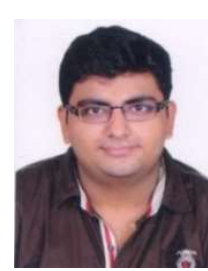

Dhruv J. Desai, Presently studing in the final year civil engineering at M.H.SabooSiddikcollege of engineering (Mumbai University). He has also presented preliminary report on "ENGINEERING ECONOMICS AND LIFE CYCLE COST ANALYSIS" at the college level. He is a construction management aspirant at Masters level. He is presently also working in research areas of costing and tendering.

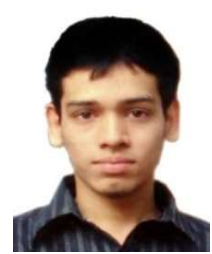

Tejas H. Jain, He is pursuing Bachelors Degree in Civil Engineering from SabooSiddik College of Engineering. He has keen interest in research and he wishes to make contributions to the society by becoming a great engineer. $\mathrm{He}$ has presented papers in International journals and International conferences. He has done internship with different construction companies.

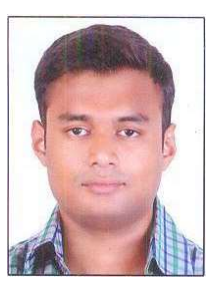

Atul Dwivedi, Student of be civil in M.H.Saboosiddik College of Engineering. $\mathrm{He}$ is interested in pursuing career in project management. Also a Masters aspirant in the field of construction management, he has given competitive exams for higher studies.

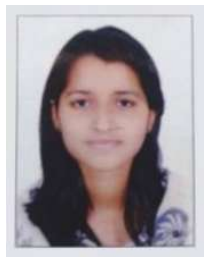

Anjum D. Attar, She has completed diploma in civil engineering from VJTI and currently pursuing bachelors in civil engineering from the M.H.SABOO SIDDIK COLLEGE OF ENGINEERING. Being a civil engineer, author want to bring in the best of advancements in the field of civil engineering that will benefit the mankind and the human race because "being a civil engineer is being a creator" 